EESTI NSV TEADUSTE AKADEEMIA TOIMETISED. XVII KOIDE

KEEMIA * GEOLOOGIA. 1968, Nr. 4

ИЗВЕСТИЯ АКАДЕМИИ НАУК ЭСТОНСКОИ ССР. ТОМ ХVII

Химия - ГЕоЛОГия. 1968, ㅅ․ 4

Э. ПОБУЛ, Р. ВАХЕР, Э. АРВИСТО

\title{
ФИЗИЧЕСКИЕ СВОЙСТВА ПОРОД КРИСТАЛЛИЧЕСКОГО ФУНДАМЕНТА ЭСТОНИИ
}

О физических свойствах пород кристаллического фундамента Эстонии до последнего времени имелись очень скудные сведения. Были известны лишь данные о плотности и магнитных свойствах, определенные по единичным образцам из нескольких буровых скважин.

В течение последних пяти лет Управлением геологии Совета Министров ЭССР были пробурены многие десятки новых буровых скважин, достигших кристаллического фундамента. Это позволило более подробно изучить вещественный состав и физические свойства пород.

Настоящая статья яв.ляется сводкой изучения физических свойств пород кристаллического фундамента Эстонии в период с 1962 по 1967 год.

До настоящего времени опубликованы лишь результаты определения физических свойств указанных пород на участке Ульясте (Побул, Ваxep, 1964).

Образцы пород были отобраны из керна буровых скважин и описаны сотрудниками Управления геологии СМ ЭССР (Я. Я. Кивисилла, Х. Э. Кихно, Х. Я. Коппельмаа и др.) и Тартуского государственного университета (Т. И. Кууспалу). Плотность пород определена в Управлении геологин СМ ӘССР по 4605 образцам из 74 скважин (в том числе 1567 образцов выветрелых пород и 3038 образцов свежих пород). Магнитные свойства определены в Институте геологии АН ЭССР по 1485 образцам из 62 скважин (в том числе 453 образца выветрелых пород и 1032 образца свежих пород).

Расположение буровых скважин иллюстрируется рис. 1.

Плотность $\sigma$ определена денситометром ИПС на воздушно-сухих образцах. Контрольные измерения произведены в объеме $2,2 \%$. Средняя квадратичная ошибка измерения составляет $\pm 0,01 \mathrm{z} / \mathrm{cm}^{3}$.

Магнитные свойства образцов определялись магнитометрами М-14Ф и $\mathrm{MA}-21$.

При измерении магни гометром М-14Ф применялась методика наблюдений, разработанная Б. Ш. Русиновым (1960). Контрольные измерения проведены в объеме $4,2 \%$. Средняя относительная ошибка составляла при измерении кажущейся магнитной восприимчивости $x^{\prime} \pm 9,7 \%$, при измерении естественной остаточной намагниченности $I_{n} \pm 6,8 \%$.

Измерения магнитометром МА-21 проводились согласно инструкции; приложенной к прибору. Объъем контрольных измерений - 10\%; средняя относительная ошибка при измерении $x^{\prime} \pm 1,1 \%$, при измерении $I_{n} \pm 2,9 \%$. 


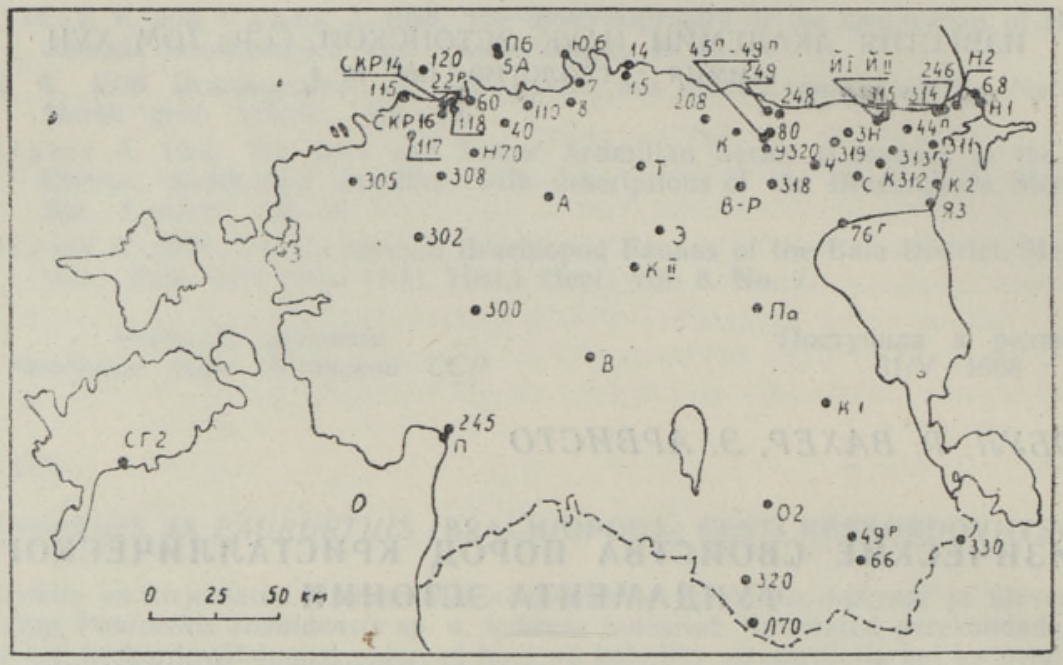

Рис. 1. Схема расположения буровых скважин.

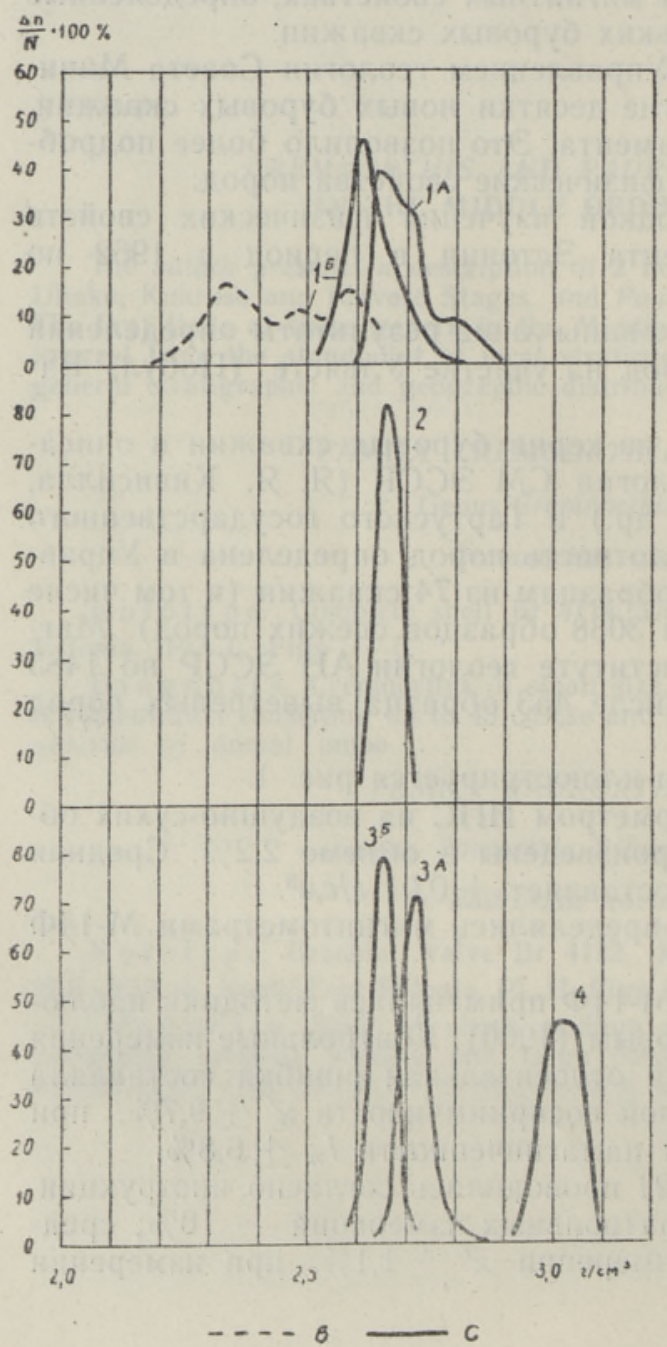

По восьми образцам проведены контрольные измерения как магнитометром $M-14 \Phi$, так и магнитометром MA-21. Средняя относительная ошибка составляла соответственно при измерении $x^{\prime} \pm 7,0 \%$ и $\pm 0,7 \%$, при измерении $I_{n} \pm 1,8 \%$ и $\pm 0,5 \%$. Систематической ошибки не обнаружено.

При статистической обработке результатов измерения плотности, магнитной восприимчивости и остаточной намагниченности полученные данные группировались по разновидностям пород (табл. 1), согласно принятой Т. И. Кууспалу, Я. Я. Кивисилла, Х. Э. Кихно и Х. Я. Коппельмаа классификации.

Для каждой разновидности пород (количество образцов более 30 ) построены вариационные кривые распределения

Рис. 2. Вариационные кривые распределения плотности:

l- траниты мнкроклиновые и плагиомикроклиновые: $A$ - участка П̈ыхви, $N_{\mathrm{c}}=96, \quad B-$ oстальные, $N_{\mathrm{c}}=215, N_{\mathrm{B}}=$ $=125 ; 2$ граниты ортоклазовые, $N_{\mathrm{c}}=30$; 3 - граниты рапакнви: $A$ - Мярьямааского массива, $N_{c}=182,5-$ Haйсcаарского и Эредаского массивов, $N_{\mathrm{c}}=118$; 4 - габбро-нориты, $N_{\mathrm{c}}=48 . N^{-}$- количество образцов; в - выветрелые породы: с - свежие породы. 
плотности (рис. 2 и 3). С целью облегчения сравнения кривых между собой при группировании данных выбран единый интервал $\Delta x=0,52 / \mathrm{cm}^{3}$.

Вычислены следующие статистические параметры распределения плотности пород (табл. 1) по формулам:

среднее арифметическое

$$
\bar{x}=\frac{\sum_{i=1}^{k} \bar{x}_{i} \cdot n_{i}}{N},
$$

стандарт

$$
S=\sqrt{\frac{\sum_{i=1}^{k}\left(\bar{x}_{i}-\bar{x}\right)^{2} \cdot n_{i}}{N-1}}
$$

отношение асимметрии к ее среднему квадратичному отклонению

$$
\frac{A}{\sigma_{A}}=\frac{\sum_{i=1}^{k}\left(\bar{x}_{i}-\bar{x}\right)^{3} \cdot n_{i}}{N \sqrt{\frac{6}{N}}}
$$

отношение эксцесса к его среднему квадратичнюму отклонению

$$
\frac{E}{\sigma_{E}}=\frac{\sum_{i=1}^{k}\left(\bar{x}_{i}-\bar{x}\right)^{4} \cdot n_{i}}{N \cdot 2 \sqrt{\frac{6}{N}}} .
$$

В этих формулах $k$ - количество интервалов, $n_{i}-$ количество образцов в $i$-интервале, $N$ - общее число образцов, $\bar{x}_{i}$ - среднее значение $i$-интервала.

Гипотеза о нормальном распределении плотности принята как непротиворечащая эмпирическим данным, если выполнены два неравенства:

$$
\left|\frac{A}{\sigma_{A}}\right|<3 \quad \text { и }\left|\frac{E}{\sigma_{E}}\right|<3 \quad \text { (Руководство ..., 1965). }
$$

В противном случае проводилась проверка гипотезы о соответствии эмпирических данных логнормальному распределению.

Для выветрелых пород вычислено только среднее арифметическое значение плотности.

В пределах каждой разновидности пород среднее значение $x^{\prime}$ и $I_{n}$ вычислялось по отдельным скважинам как среднеарифметическое. Результаты определения магнитных свойств и плотности одних и тех же образцов пород по отдельным скважинам приведены в табл. 2 .

По Н. В. Дортман, «подсчет среднего значения магнитной воспринмчивости пород в пределах крупных районов при большом диапазоне

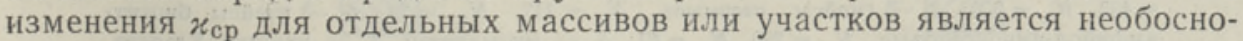

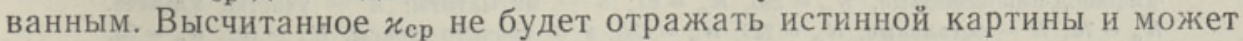
привести лишь к ложным выводам при использовании средних данных в процессе геологической интерпретации магнитных полей» (Дортман и др., 1964).

Вычисление других характерных статистических параметров, кроме 
396

Э. Побул, Р. Вахер, Э. Арвисто

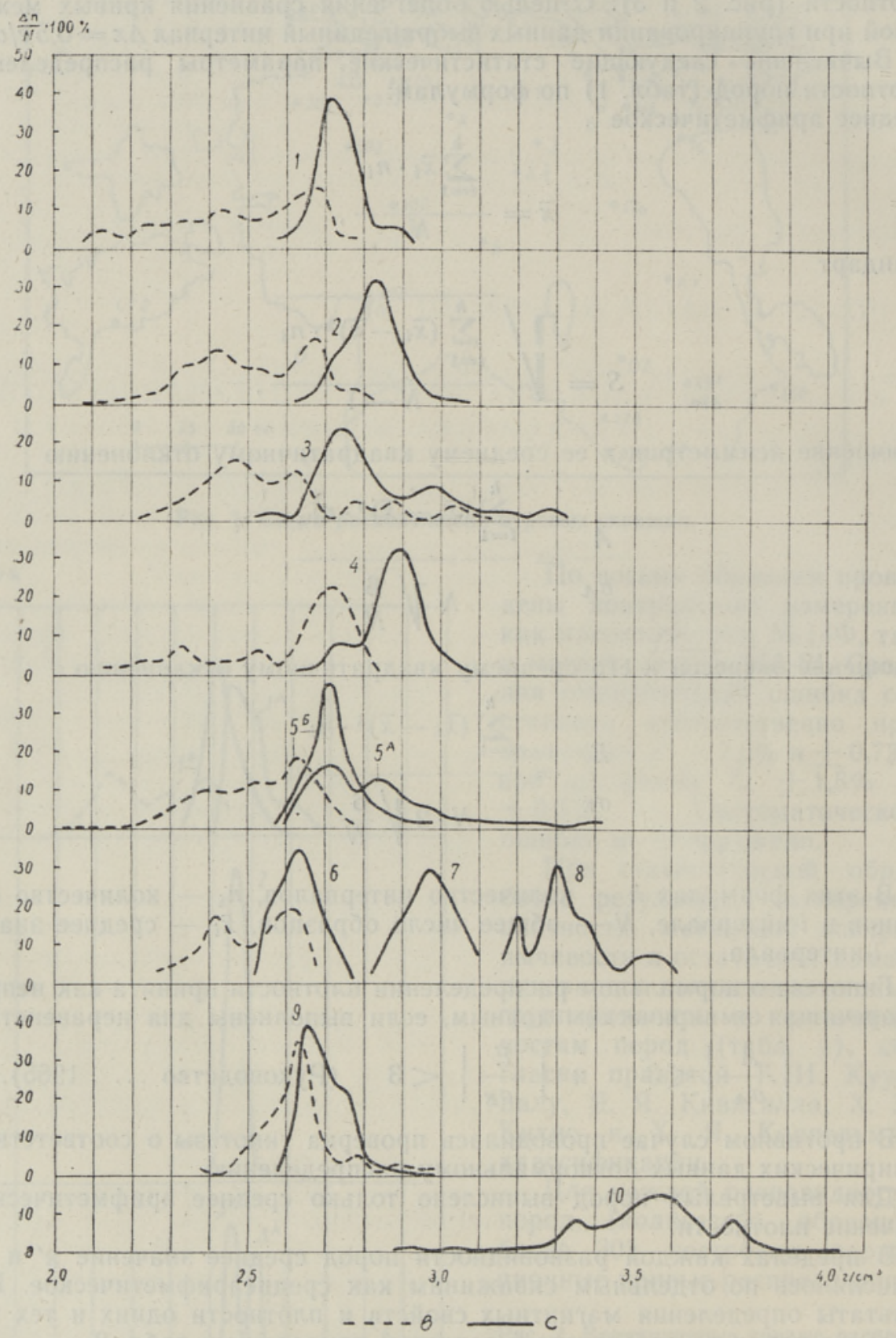

Рнс. 3. Вариационные кривые распределения плотности:

1 - гнейсы бнотитовые, $N_{\mathrm{c}}=130, N_{\mathrm{B}}=249 ; 2-$ гнейсы высокоглиноземистые, $N_{\mathrm{c}}=$ $=433, N_{\mathrm{B}}=320 ; 3-$ гнейсы «черные», $N_{\mathrm{c}}=117, N_{\mathrm{B}}=72 ; 4$ - гнейсы биотитамфибсл-пироксеновые, $N_{\mathrm{e}}=226, N_{\mathrm{B}}=61 ; 5-$ мигматиты: $A$ - участка Ульясте, $N_{\mathrm{c}}=70 ; \quad 5$ - осталығые, $N_{\mathrm{c}}=229, N_{\mathrm{B}}=430 ; 6-$ гранито-гнейсы, $N_{\mathrm{c}}=122, N_{\mathrm{B}}=56$; 7 - амфиболиты, $N_{\mathrm{c}}=81 ; 8$ - пироксеновая лорода, $N_{c}=30 ; 9$ - кварциты, $N_{\mathrm{c}}=238, N_{\mathrm{B}}=61: 10-$ магнетитовые кварциты, $N_{\mathrm{c}}=238 . N-$ количество образцов; в - выветрелые породы; с - свежне породы. 


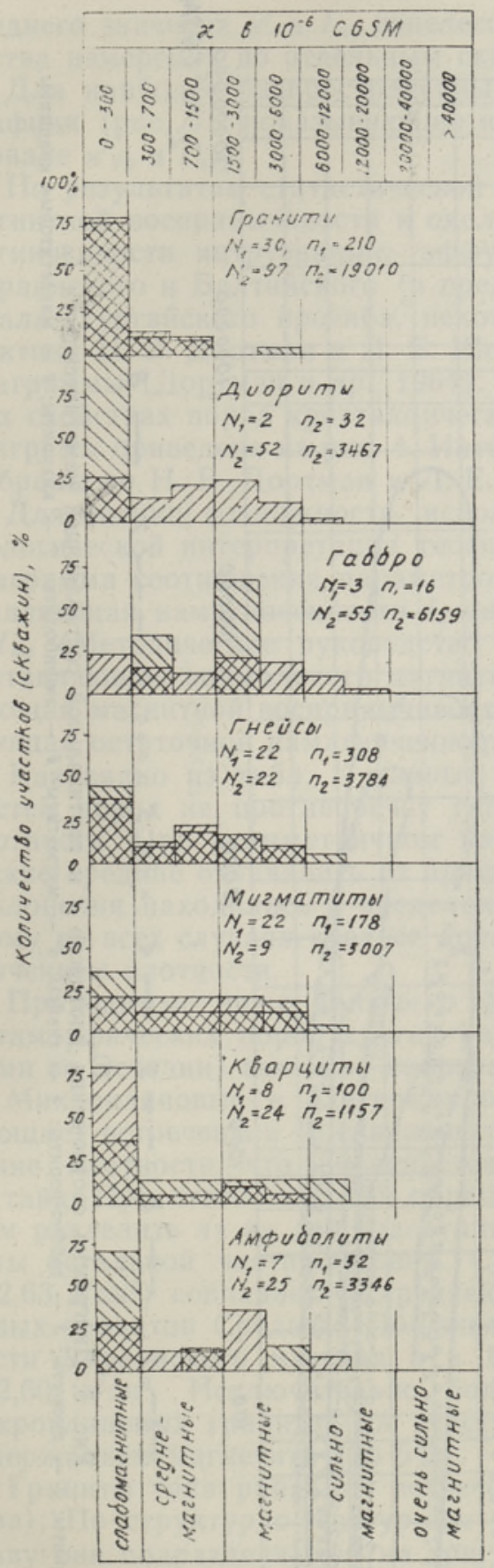

AIIV

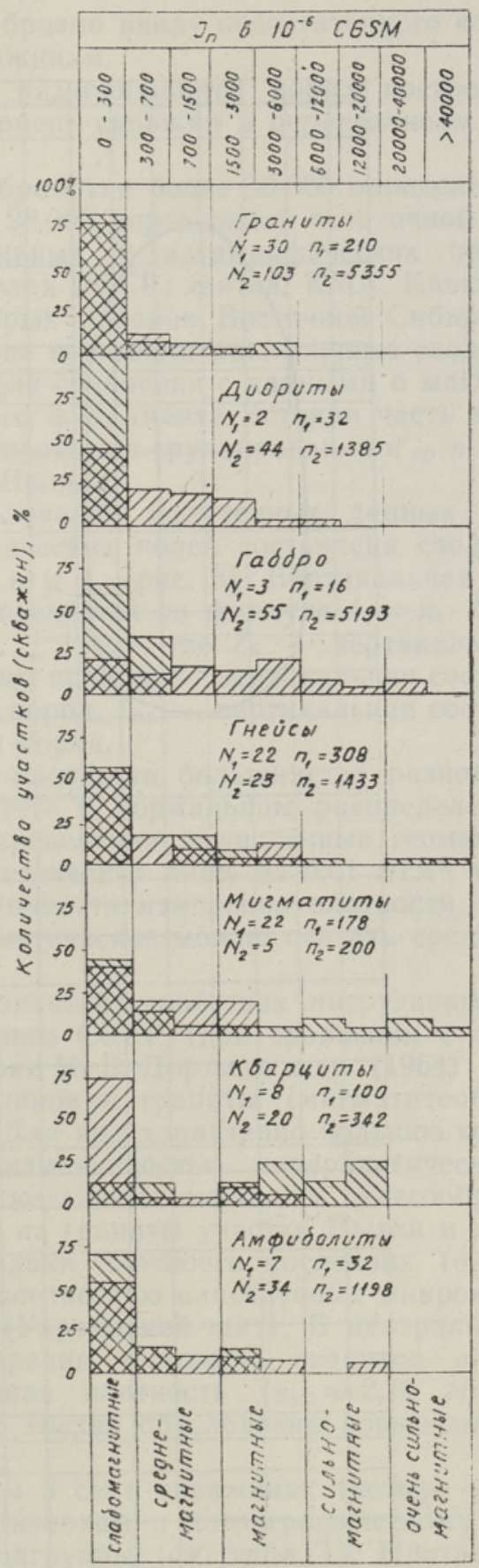

2

Рис. 4. Гистограммы распределения магннтных свойств:

1 - ЭССР, 2 - СССР (по Н. В. Дортман и др., 1964). $N$ - количество участков (для СССР) или скважин (для ЭССР); $n$ - количество образцов, 


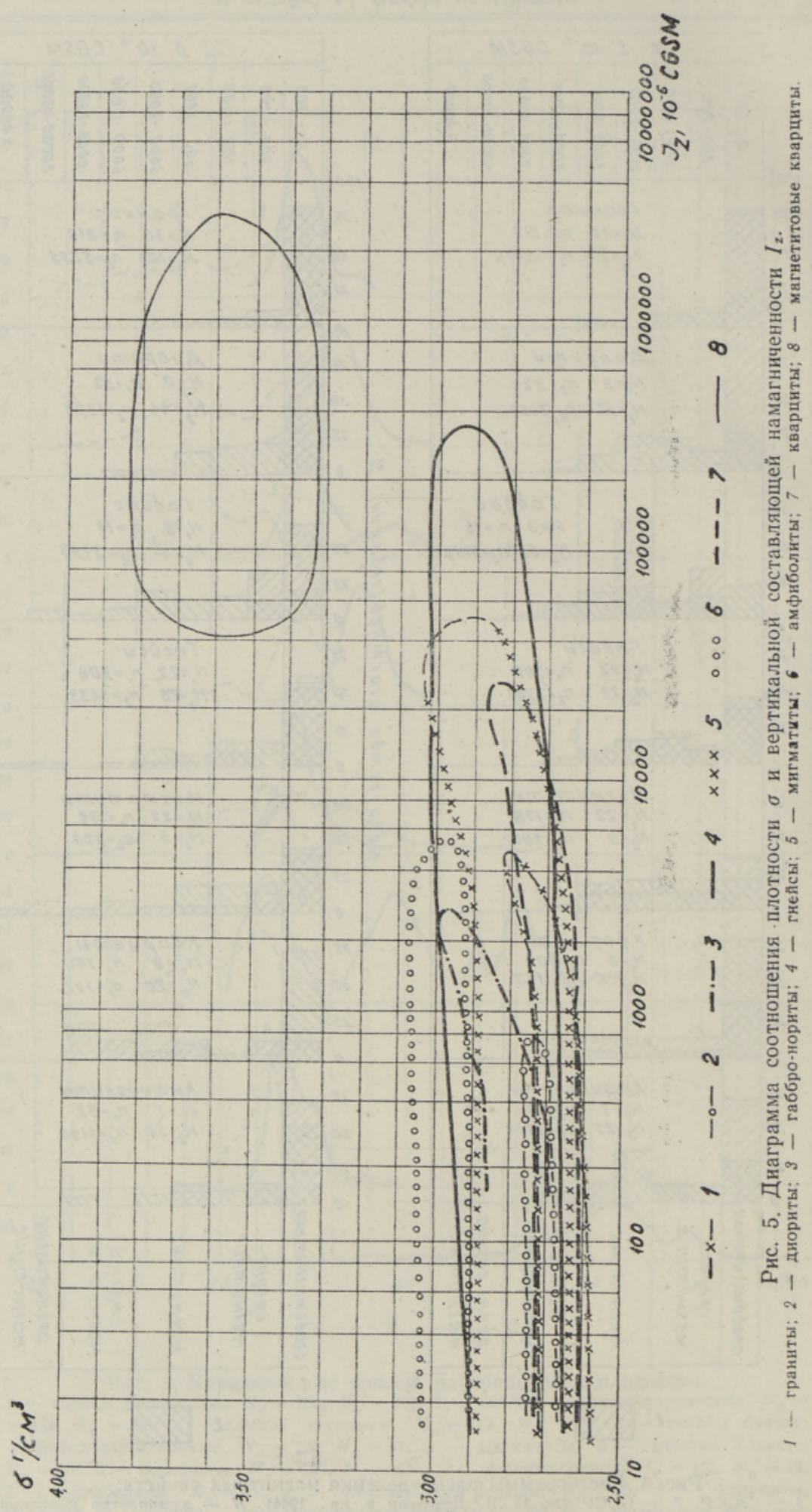


среднего значения $\varkappa^{\prime}$ и $I_{n}$, нецелесообразно ввиду недостаточного количества измерений по отдельным скважинам.

Для наиболее распространенных разновидностей пород построены графики (рис. 4), показывающие процент скважин в определенном интервале $\varkappa_{\text {ср }}^{\prime}$ и $I_{n \text { ср. }}$.

По результатам статистической обработки более 90000 определений магнитной восприимчивости и около 28000 определений остаточной намагниченности интрузивных, эффузивных и метаморфических пород Украинского и Балтийского (в пределах СССР) шитов, КМА, Кавказа, Урала, Тургайского прогиба, некоторых районов Восточной Сибири и Арктики Н. В. Дортман и Л. Е. Шолпо составили аналогичные сводные диаграммы (Дортман и др., 1964). Для сравнения с данными о магнитных свойствах пород кристаллического фундамента Эстонии часть этих диаграмм приведена на рис. 4 . Интервалы при группировании $x_{\text {ср }}^{\prime} I_{n \text { ср }}$ выбраны по Н. В. Дортман и Л. Е. Шолпо.

Для оценки возможности использования полученных данных при геологической интерпретации геофизических полей составлена сводная диаграмма соотношения параметров $\sigma$ и $I_{z}$ (рис. 5). Вертикальная составляющая намагниченности $I_{z}$ определяется по формуле $I_{z}=\varkappa_{z} \cdot Z_{0}+$ $+I_{n z}$ (Методическое руководство ..., 1962), где $Z_{0}$ - вертикальная составляющая нормального магнитного поля, $x_{z}$ - вертикальная составляющая магнитной восприимчивости пород, $I_{n z}$ - вертикальная составляющая остаточной намагниченности пород.

Как видно из табл. 1, данные о плотности большинства разновидностей пород не противоречат гипотезе о нормальном распределении плотности. При асимметричном распределении вычисленные геометрические средние отличались от арифметических лишь на 0,01 2/cm ${ }^{3}$, т. е. отклонения находились в пределах точности измерения плотности. Поэтому во всех случаях среднее арифметическое можно считать средним значением плотности.

Приводимые ниже данные о физических свойствах интрузивных и метаморфических -пород других районов СССР (при сравнении с данными по Эстонии) взяты из монографии Н. В. Дортман и др. (1964).

Микроклиновые и плагиомикроклиновые граниты (мигматитообразующие) встречены в 40 скважинах. Для них характерно большое колебание плотности, что объясняется изменчивостью минералогического состава. При статистической обработке данных оказалось целесообразным разделить их на две подгруппы: на граниты участка Йхви и грағнты остальной части Эстонии. Средняя плотность последних ( $\sigma_{\text {cp }}=$ $\left.=2,632 / \mathrm{cm}^{3}\right)$ совпадает со средней плотностью аляскитовых микроклиновых гранитов Среднего Побужья (Украинский щит). В центральной части Украинского массива и в Қарелии плотность гранитов $\sigma_{\text {cp }}=$ $=2,60 \mathrm{z} / \mathrm{cm}^{3}$. Исключительно большая плотность $\left(\sigma_{\mathrm{cp}}=2,70 \mathrm{2} / \mathrm{cm}^{3}\right)$ микроклиновых гранитов на участке Иыхви обусловлена повышенным содержанием магнетита (до $5 \%$ ).

Граниты типа рапакиви встречены в семи скважинах (четыре массива). По структурно-текстурным признакам и петрографическому составу они подразделяются на три подгруппы (см. табл. 1). Плотность

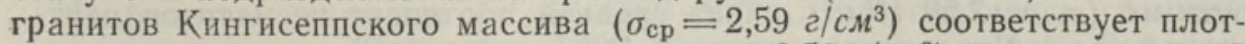

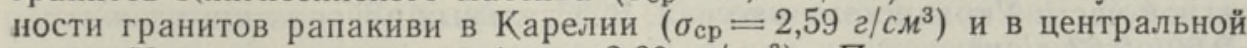
части Украинского щита $\left(\sigma_{\mathrm{cp}}=2,60 \mathrm{z} / \mathrm{cm}^{3}\right)$. Повышенная плотность

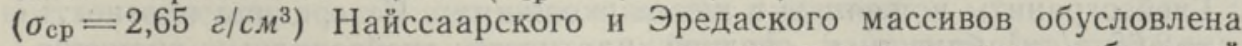
увеличением содержания цветных минералов и плагиоклаза и большей основностью плагиоклаза. Исключительно высокая плотность $\left(\sigma_{\mathrm{cp}}=\right.$ $=2,72$ г/см ${ }^{3}$ рапакиви Мярьямааского массива объясняется большим со- 
Плотность и минералогический состав пород

(Минералогнческий состав приведен по я. Я. Кивисилла,

\begin{tabular}{|c|c|c|c|c|c|c|c|c|c|c|c|}
\hline \multirow{3}{*}{ 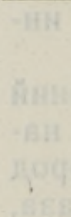 } & \multirow{3}{*}{\multicolumn{2}{|c|}{ Название породы }} & \multicolumn{4}{|c|}{ Выветрелые породы } & & & & \multirow{2}{*}{\multicolumn{2}{|c|}{ Параметры $\sigma$}} \\
\hline & & & & & $\sigma, \quad 2 / c$ & + & & & & & \\
\hline & & & 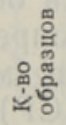 & средн. & мин. & макс. & 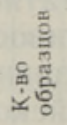 & средн. & мин & маке. & $S$ \\
\hline
\end{tabular}

Граниты микроклиновые и пла . гиомнкроклиновые

участка Пыхви

остальные

Граниты ортоклазовые (орточарнокнты)

Граниты рапакиви

Кингисеппский массив

Найссаарский и Эредаский

массивы

Мярьямааский массив

\section{Пегматнты}

Гнейсо-граниты

Гранодиориты

Диорнт кварцевый

участка Ласнамяэ

участка Арукюла

Диорит кварцевый измененный Габбро-диорнт

Габбро-норит

Габбро-норит амфиболизированный

Сланцы биотит-амфнбол-пироксеновые

Гранито-гнейс

Гнейс биотитовый

Гнейсы высокоглиноземистые

Гнейсы «черные»

Гнейсы биотит-амфибол-пнроксе-

новые

Мнгматиты

участка Ульясте

остальные

Амфнболиты

Мраморы

Кварциты

участка Отепя

участка Ульясте

Кварциты магнетитовые

Пнроксеновая порода

\begin{tabular}{|c|c|c|c|c|c|c|c|c|}
\hline $\begin{array}{r}10 \\
125\end{array}$ & $\begin{array}{l}2,67 \\
2,44\end{array}$ & $\begin{array}{l}2.60 \\
2.02\end{array}$ & $\begin{array}{l}2,71 \\
2,64\end{array}$ & $\begin{array}{r}96 \\
215\end{array}$ & $\begin{array}{l}2,70 \\
2,63\end{array}$ & $\begin{array}{l}2,63 \\
2,54\end{array}$ & $\begin{array}{l}2,88 \\
2,82\end{array}$ & $\begin{array}{l}0.06 \mathrm{I} \\
0.046\end{array}$ \\
\hline- & - & - & - & 30 & 2,65 & 2,59 & 2.67 & 0.020 \\
\hline 8 & 2,40 & 2,22 & 2,55 & 12 & 2.59 & 2,55 & 2.60 & - \\
\hline 23 & 2.44 & 2,33 & 2,60 & 118 & 2.65 & 2,62 & 2,70 & 0,026 \\
\hline - & - & - & - & 182 & 2,72 & 2,65 & 2,88 & $0.03 \mathrm{t}$ \\
\hline $\begin{array}{l}28 \\
18\end{array}$ & $\begin{array}{r}2,51 \\
2,41 \\
-\end{array}$ & $\begin{array}{c}2,19 \\
2,20 \\
-\end{array}$ & $\begin{array}{c}2,65 \\
2,60 \\
-\end{array}$ & $\begin{array}{l}11 \\
20 \\
10\end{array}$ & $\begin{array}{l}2,59 \\
2,66 \\
2,71\end{array}$ & $\begin{array}{l}2,54 \\
2,6 ! \\
2,69\end{array}$ & $\begin{array}{l}2,63 \\
2,72 \\
2,77\end{array}$ & $\overline{-}$ \\
\hline & - & & - & 6 & 2,81 & 2,80 & 2,83 & $\rightarrow$ \\
\hline 8 & 2,44 & 2,30 & 2,58 & 8 & 2,73 & 2,72 & 2,74 & - \\
\hline $\begin{array}{l}13 \\
12 \\
10\end{array}$ & $\begin{array}{l}2,40 \\
2,48 \\
2,35\end{array}$ & $\begin{array}{l}2,27 \\
2,16 \\
1,96\end{array}$ & $\begin{array}{l}2,57 \\
2,75 \\
2,87\end{array}$ & $\begin{array}{l}29 \\
13 \\
48\end{array}$ & $\begin{array}{l}2,74 \\
2,83 \\
3,03\end{array}$ & $\begin{array}{l}2,66 \\
2,79 \\
2,94\end{array}$ & $\begin{array}{l}2,80 \\
2,86 \\
3,06\end{array}$ & $\overline{0.042}$ \\
\hline 11 & 2,42 & 2,16 & 2,70 & 23 & 2,87 & 2,79 & 2,98 & - \\
\hline $\begin{array}{r}\overline{56} \\
249 \\
320 \\
72\end{array}$ & $\begin{array}{l}- \\
2,50 \\
2,47 \\
2,52 \\
2,57\end{array}$ & $\begin{array}{l}-\overline{2,26} \\
2,08 \\
2,09 \\
2,27\end{array}$ & $\begin{array}{l}\overline{2}, 66 \\
2,78 \\
2.82 \\
3.05\end{array}$ & $\begin{array}{r}16 \\
122 \\
130 \\
433 \\
117\end{array}$ & $\begin{array}{l}2,96 \\
2,64 \\
2,73 \\
2,82 \\
2,81\end{array}$ & $\begin{array}{l}2,86 \\
2,54 \\
2,58 \\
2,63 \\
2,54\end{array}$ & $\begin{array}{l}3.12 \\
2.84 \\
2.91 \\
3.06 \\
3.29\end{array}$ & $\begin{array}{l}\overrightarrow{0,055} \\
0,063 \\
0.070 \\
0,149\end{array}$ \\
\hline 61 & 2,59 & 2,10 & 2,88 & 226 & 2,87 & 2,63 & 3,12 & 0.084 \\
\hline $\begin{array}{r}430 \\
24 \\
4\end{array}$ & $\begin{array}{l}-\overline{53} \\
2,43 \\
2,74\end{array}$ & $\begin{array}{l}\overrightarrow{1,92} \\
1,53 \\
2,66\end{array}$ & $\begin{array}{l}-\overline{84} \\
3,01 \\
2,77\end{array}$ & $\begin{array}{r}70 \\
229 \\
81 \\
20\end{array}$ & $\begin{array}{l}2,83 \\
2,72 \\
2,96 \\
2,86\end{array}$ & $\begin{array}{l}2,62 \\
2,57 \\
2,81 \\
2,74\end{array}$ & $\begin{array}{l}3,42 \\
2,99 \\
3.07 \\
3,08\end{array}$ & $\begin{array}{c}0.177 \\
0,070 \\
0.064 \\
-\end{array}$ \\
\hline $\begin{array}{r}61 \\
25 \\
3\end{array}$ & $\begin{array}{l}-\overline{63} \\
3,11 \\
2,87\end{array}$ & $\begin{array}{l}-\overline{32} \\
2,70 \\
2,84\end{array}$ & $\begin{array}{l}-\overline{10} \\
3.102 \\
2.90\end{array}$ & $\begin{array}{r}5 \\
238 \\
238 \\
30\end{array}$ & $\begin{array}{l}2.62 \\
2.70 \\
3.54 \\
3.33\end{array}$ & $\begin{array}{l}2,60 \\
2,60 \\
2,89 \\
3,18\end{array}$ & $\begin{array}{l}2,64 \\
2,94 \\
4,07 \\
3.58\end{array}$ & $\begin{array}{l}-\overline{062} \\
0.197 \\
0.111\end{array}$ \\
\hline
\end{tabular}

\footnotetext{
* Биотит и мусковнт.

*2 Наfнссаарский массив - N 5-11. Эредаский массив -- $N_{2} 30-42$.

*3 Зональное строенне.

*4 Сфен 2-3\%, апатит $1-3 \%$

*5 Элидот $5--20 \%$.
}

держанием акцессорных минералов. Анормальное распределение их плотности связано, по-видимому, с характером изменения содержания магнетита.

Пегматиты (секущие) встречены в десяти скважинах. Средняя плотность их $\left(\sigma_{\mathrm{cp}}=2,592 / \mathrm{cm}^{3}\right)$ равна средней плотности пегматитов центральной части Украинского массива. В остальных районах щитов $\sigma_{c p}=$ $=2,60-2,63$ г/ $\mathrm{CM}^{3}$.

Гнейсограниты встречены в шести скважинах. Их средняя плотность

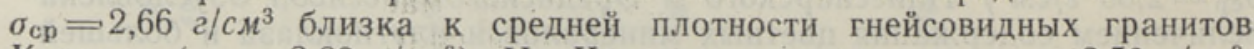

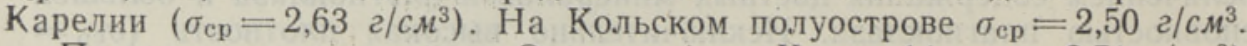

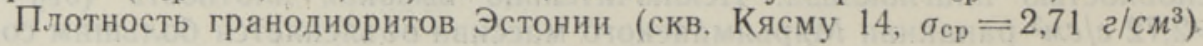


кристаллического фундамента Эстонии

Х. э. Кихно, Х. Я. Коппельмаа и Т. И. Кууспалу)

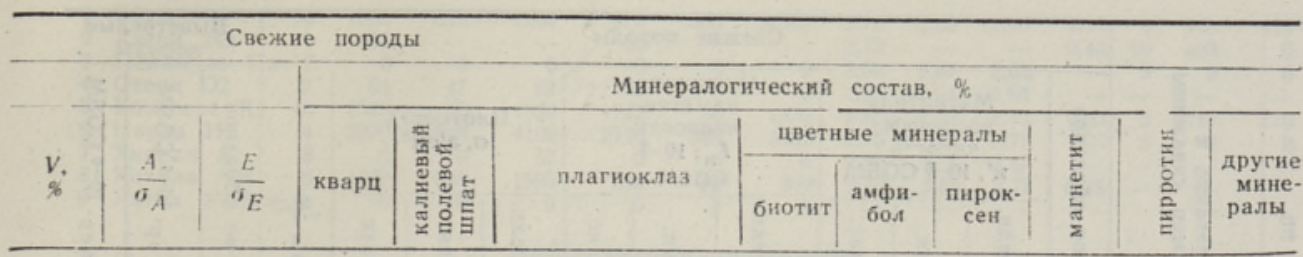

\begin{tabular}{|c|c|c|c|c|c|c|c|c|c|c|c|c|}
\hline $\begin{array}{l}2,27 \\
1,73\end{array}$ & $\begin{array}{l}1,18 \\
1,16\end{array}$ & $\begin{array}{r}0,37 \\
-0,49\end{array}$ & $\begin{array}{l}10-20 \\
20-40\end{array}$ & $\begin{array}{l}50-70 \\
30-70\end{array}$ & $\begin{array}{r}5 \\
0-40\end{array}$ & $N=10-35$ & $\frac{5}{0}-15^{*}$ & $0-\overline{5}$ & $0-\overline{5}$ & $\frac{0-5}{-}$ & - & \\
\hline 0,75 & 2,79 & $-3,36$ & $25-30$ & $45-55$ & $15-20$ & N. $29-34$ & $3-5$ & - & $0-3$ & - & - & \\
\hline- & - & - & 30 & 53 & 10 & Ni 0 & 5 & - & - & - & - & \\
\hline 0,98 & $-0,48$ & $-1,35$ & $20-25$ & $35-50$ & $15-35$ & $N_{2}^{* 2}$ & $7-8^{*}$ & - & $=$ & - & - & \\
\hline 1,12 & 5,60 & 9,26 & $20-25$ & $35-40$ & $25-30$ & $\begin{array}{ll}\text { No } 15-25 \\
\text { № } 30-37^{* 3}\end{array}$ & $6-10$ & - & - & $1-4$ & - & *4 \\
\hline - & - & - & $20-45$ & $20-50$ & $20-40$ & $N_{2} 10-30$ & $5-15^{*}$ & - & - & - & - & 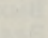 \\
\hline$\overline{-}$ & - & - & $\begin{array}{r}20-30 \\
35\end{array}$ & $20-30$ & $\begin{array}{l}30-40 \\
45-50\end{array}$ & $\begin{array}{l}\text { № } 20-30 \\
\text { № } 36\end{array}$ & $\begin{array}{r}5-15 \\
10-15\end{array}$ & - & - & - & - & \\
\hline - & - & - & $20-25$ & & $55-60$ & $\begin{array}{l}\text { № } 43-51 \\
﹎{2} 70-80^{* 3}\end{array}$ & $10-12$ & $5-6$ & - & - & - & \\
\hline - & - & - & $25-30$ & $10-12$ & $35-40$ & $\begin{array}{l}\text { № } 30-38 \\
\text { № } 52-55^{* 3}\end{array}$ & $10-12$ & $3-4$ & - & - & 一 & \\
\hline- & - & - & $5-20$ & - & $40-70$ & N. $6-8$ & $5-20$ & - & - & - & - & *s \\
\hline $1, \overline{39}$ & $-2, \overline{79}$ & $-0, \overline{91}$ & - & - & $\begin{array}{l}60-65 \\
55-60\end{array}$ & $\begin{array}{l}\text { No } 40-4 ! \\
N_{2} 52\end{array}$ & - & 5 & $\begin{array}{l}25-30 \\
40-45\end{array}$ & $0-\overline{2}$ & $\overline{-}$ & 1 \\
\hline- & - & -7 & & - & $55-65$ & $N_{2} 47-48$ & $0-5$ & $20-25$ & $10-15$ & $0-2$ & - & \\
\hline- & - & & & - & $0-7$ & & 35 & $0-30$ & $20-45$ & - & - & \\
\hline 2,10 & 0,32 & $-0,34$ & $15-4 \dot{5}$ & $5-50$ & $10-45$ & & $5-15$ & - & $20-$ & - & - & \\
\hline 2,31 & 0,75 & 0,23 & $25-40$ & $0-40$ & $10-45$ & & $5-25$ & - & - & $0-2$ & - & \\
\hline 2.48 & $-0,27$ & $-0,30$ & $20-40$ & $10-40$ & $0-25$ & & $5-20$ & $\rightarrow$ & - & $0-10$ & - & $\theta \bar{G}$ \\
\hline 5,30 & 5,34 & 2,47 & $0-40$ & $0-65$ & $5-50$ & & $5-20$ & - & - & - & $0-20$ & $* 7$ \\
\hline 2,93 & $-2,22$ & $-1,70$ & $5-25$ & $0-30$ & $25-50$ & & $0-20$ & $0-30$ & $0-40$ & $0-4$ & - & . \\
\hline 6,25 & 4,60 & 2,74 & & & & & & & & & & \\
\hline $\begin{array}{l}2,57 \\
2,17\end{array}$ & $\begin{array}{l}1,09 \\
0,31\end{array}$ & $\begin{array}{r}-0,32 \\
-1,42\end{array}$ & $0-10$ & $0-5$ & $25-45$ & & $0-15$ & $50-70$ & $0-5$ & $0-4$ & & \\
\hline- & - & $-1,72$ & - & - & - & & - & - & $0-30$ & - & $5-10$ & $* 3$ \\
\hline - & - & & 70 & & & & - & - & - & - & $1-$ & \\
\hline 2,29 & 4,65 & 2,08 & $90-98$ & - & - & 1 & & $0-3$ & $1-5$ & - & $0-10$ & \\
\hline 5,57 & $-2,40$ & 1,04 & $20-50$ & $0-40$ & $0-5$ & 1. & $0-5$ & $0-35$ & $0-40$ & $20-35$ & - & $* 9$ \\
\hline 3,30 & 2,09 & -0.32 & - & & - & & - & - & $75-98$ & - & $0-25$ & \\
\hline
\end{tabular}

$\Rightarrow$ Кордиерит $0-25 \%$. гранат $0-20 \%$, силлиманит $0-10 \%$.

$* 7$ Кордиерит $0-20 \%$. гранат $0-20 \%$.

\&s Кальцит $60-80 \%$, оливнн и серпентин $0-20 \%$

*4 Гранат $5-20 \%$.

соответствует плотности гранодиоритов Среднего Побужья (Украина). В остальных районах щитов $\sigma_{\mathrm{ep}}=2,65-2,692 / \mathrm{cm}^{3}$.

Магнитные свойства гранитов характеризуются изменением $\varkappa_{\text {ср }}^{\prime}$ $I_{n \text { cp }}$ отдельных скважин в пределах от 0 до $6000 \cdot 10^{-6} \mathrm{CGSM}$. Подавляющее большинство гранитов - слабомагнитные (см. рис. 4).

Наиболее магнитными $\left(\varkappa^{\prime}\right.$ сp $=4360 \cdot 10^{-6}$ CGSM) оказались граниты рапакиви скважины Ваймыйза 302 (Мярьямааский массив). Высокая магнитность их должна рассматриваться как исключение, обусловленное генетическими особенностями массива рапакиви.

Остаточная намагниченность гранитов $I_{n}$ изменяется в пределах $0-3000 \cdot 10^{-6}$ CGSM, но $I_{\text {ep }}$ в $86 \%$ скважин находится в интервале $0-300 \cdot 10^{-6}$ CGSM. 
Таблица 2

Магнитные свойства пород кристаллнческого фундамента Эстонии

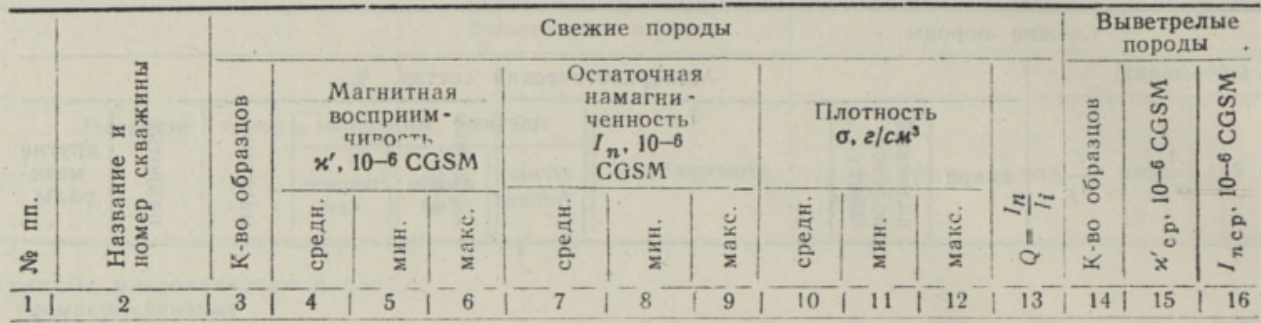

Граниты микроклиновые и плагиомикроклиновые

$\begin{array}{rlr}1 & \text { Вока 315 } & 2 \\ 2 & \text { Пыхви ПІ } & 29 \\ 3 & \text { Азери 249 } & 1 \\ 4 & \text { Нарва Н2 } & 6 \\ 5 & \text { Кейла 117 } & 10 \\ 6 & \text { Прангли 5A } & 2 \\ 7 & \text { Выхма B } & 4 \\ 8 & \text { Эллавере 9 } & 1 \\ 9 & \text { Отепя О2 } & 12 \\ 10 & \text { Каагвере К1 } & 4 \\ 11 & \text { Пудисоо 7 } & 6 \\ 12 & \text { Хирвли 8 } & 10 \\ 13 & \text { Кабала К } & 6 \\ 14 & \text { Кынну 300 } & 1 \\ 15 & \text { Хаапсалу 3 } & 2 \\ 16 & \text { Печоры } 330 & 10 \\ 17 & \text { Ульясте 45п } & 2 \\ 18 & \text { Ульясте 46п } & 4 \\ 19 & \text { Ульясте 47n } & 2 \\ 20 & \text { Ульясте 48п } & 2\end{array}$

$\begin{array}{rr}0 & 0 \\ 1030 & 61 \\ 435 & - \\ 561 & 0 \\ 110 & 23 \\ 0 & 0 \\ 43 & 0 \\ 635 & - \\ 53 & 34 \\ 56 & 32 \\ 0 & 0 \\ 0 & 0 \\ 0 & 0 \\ 0 & - \\ 0 & 0 \\ 986 & 35 \\ 212 & 125 \\ 68 & 50 \\ 270 & 60 \\ 0 & 0\end{array}$

\begin{tabular}{rr}
0 & 0 \\
9200 & 4790 \\
- & 90 \\
918 & 332 \\
265 & 24 \\
0 & 0 \\
109 & 0 \\
\hline- & 80 \\
80 & 0 \\
79 & 33 \\
0 & 0 \\
0 & 0 \\
0 & 0 \\
\hline 0 & 0 \\
2600 & 0 \\
300 & 1969 \\
88 & 81 \\
480 & 3070 \\
0 & 0
\end{tabular}

\begin{tabular}{r}
0 \\
0 \\
\hline 0 \\
0 \\
0 \\
0 \\
- \\
0 \\
0 \\
0 \\
0 \\
0 \\
\hline 0 \\
0 \\
1410 \\
0 \\
435 \\
0
\end{tabular}

$\begin{array}{rlll}0 & 2,68 & 2,69 & 2,69 \\ 51800 & 2,71 & 2,64 & 2,96 \\ -\overline{2} & 2.68 & \overline{-} & \overline{-} \\ 530 & 2,71 & 2,68 & 2,73 \\ 0 & 2,63 & 2,56 & 2,67 \\ 0 & 2,56 & 2,56 & 2,56 \\ \overline{2} & 2,64 & 2,61 & 2,63 \\ 20 & 2,64 & 2, \overline{5} & 2, \overline{7} \\ 65 & 2,66 & 2,65 & 2,68 \\ 0 & 2,62 & 2,61 & 2,64 \\ 0 & 2,66 & 2,60 & 2,70 \\ 0 & 2,61 & 2,60 & 2,63 \\ - & 2,64 & \overline{-} & -\overline{0} \\ 0 & 2,70 & 2,69 & 2,70 \\ 1820 & 2,66 & 2,61 & 2,71 \\ 2440 & -\overline{-} & -\overline{-} & -\overline{1} \\ 166 & 2,62 & 2,60 & 2,66 \\ 5710 & 2,62 & 2,58 & 2,66 \\ 0 & 2,57 & 2,56 & 2,59\end{array}$

\section{Гранит ортоклазовый}

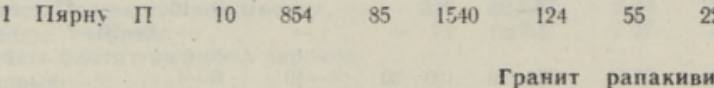

1 Ваймыйза 302

108

Кингисепп

Сг2

$4330 \quad 2400$

8370

$266 \quad 62 \quad 1230$

$2,65 \quad 2,63$

2,67

$0,29-$

Мурасте 115

4 Hah̆ccaap

5 Эреда 319

$85 \quad 33$

$145-2.61-2,59-2,61$

0,12

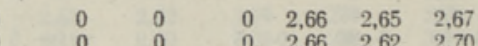

\section{Гнейсо-граннт}

Лаанеметса Л70

2 Кестла 248

3 Прангли П6

4 Кабала K

\section{Днорнты}

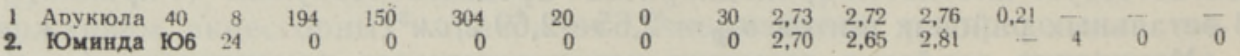

\section{Габбро-диорит}

1 Утрня $246 \quad 11 \quad 0 \quad 0000000$

\section{Габбро-нориты}

$\begin{array}{llrrrr}\text { Tana T } & 10 & 2130 & 165 & 4540 \\ 2 & \text { Пярну } & 4 & 420 & 263 & 500\end{array}$

$\begin{array}{llllllllll}441 & 75 & 831 & 2,89 & 2,85 & 2,98 & 0,41 & 2 & 69 & 0\end{array}$

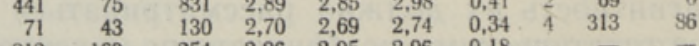

$\begin{array}{lllll}3 \text { Выру } 66 & 2 & 2360 & 2180 & 2530\end{array}$

\section{Гранито-гнейс}

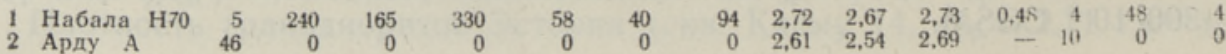




\begin{tabular}{l|l|l|l|l|l|l|l|l|l|l|l|l|l|l|l|l|l|l|l|l}
\hline $1 \mathrm{i}$ & 2 & 3 & 4 & 5 & 6 & 7 & &
\end{tabular}

$\begin{array}{llrrr}1 & \text { Вока 315 } & 10 & 1360 & 82 \\ 2 & \text { Азерн 249 } & 1 & 395 & \\ 3 & \text { Паламузе Па } & 2 & 0 & \\ 4 & \text { Отепя O2 } & 2 & 54 & 47 \\ 5 & \text { Каагвере K1 } & 10 & 2340 & 80 \\ 6 & \text { Нарва H2 } & 4 & 2000 & 63 \\ 7 & \text { Хирвли 8 } & 8 & 0 & \\ 8 & \text { Кохнла 308 } & \text { S } & 1370 & 68 \\ 9 & \text { Ухтна у320 } & 4 & 0 & \end{array}$

1 Иыхвн Гй

2 Ряэтсма 313 r 6

3 Кабала К 12

4 Сырумяэ С

5 Тарума 4

6 Ухтна у 320

\section{Гнейс бнотитовый}

$\begin{array}{rrrrrrrrrrrr}825 & 1780 & 970 & 556 & 1840 & 2,72 & 2,69 & 2,78 & 1,13 & 4 & 343 & 110 \\ - & - & 80 & - & - & 2,72 & - & - & 0,40 & 10 & 103 & 0 \\ 0 & 0 & 0 & 0 & 0 & 2,68 & 2,67 & 2,68 & - & 5 & 0 & 0 \\ 47 & 62 & 0 & 0 & 0 & 2,65 & 2,64 & 2,66 & - & - & - & - \\ 80 & 4030 & 742 & 36 & 1570 & 2,82 & 2,75 & 2,86 & 0,63 & 2 & 1210 & 110 \\ 638 & 4100 & 2190 & 340 & 4660 & 2,75 & 2,73 & 2,77 & 2,20 & 2 & 0 & 0 \\ 0 & 57 & 0 & 0 & 0 & 2.78 & 2,71 & 2,87 & - & - & - & - \\ 638 & 1990 & 238 & 52 & 540 & 2.72 & 2.68 & 2.78 & 0,35 & - & - & - \\ 0 & 0 & 0 & 0 & 0 & - & - & - & - & - & - & -\end{array}$

Гнейсы высокоглиноземистые

$\begin{array}{rrrrrrrrrrr}36600 & 75600 & 4970 & 328000 & 2,85 & 2,74 & 3,04 & 14,3 & - & - & - \\ 24 & 66 & 0 & 195 & 2,75 & 2,71 & 2.79 & - & 16 & 0 & 0 \\ 35 & 0 & 0 & 0 & 2,72 & 2,65 & 2,76 & - & 10 & 0 & 0 \\ 0 & 0 & 0 & 0 & 2,76 & 2,72 & 2,80 & - & - & - & - \\ 168 & 159 & 0 & 378 & 2,76 & 2,71 & 2,82 & 2,58 & - & - & - \\ 153 & 27 & 0 & 126 & 2,78 & 2,72 & 2,84 & 1,38 & - & - & -\end{array}$

Гнейсы кчерные»

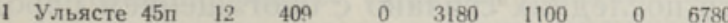

$\begin{array}{rlrrrrrrrrrrrrrr}2 & \text { Vльясте } 47 n & 21 & 1430 & 510 & 3050 & 26100 & 4920 & 89400 & 2,87 & 2,66 & 3,29 & 36,5 & 6 & 0 & 0\end{array}$

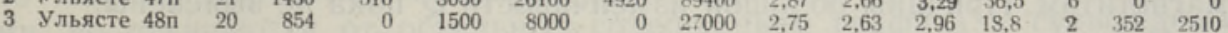

\section{Гнейсы биотит-амфнбол-пироксеновые}

1 Вока $315 \quad 24 \quad 2240$

2 Выхма В 4220

3 Эллавере $\ni \quad 4 \quad 560$

4 Кахала KII $33 \quad 4610$

$\begin{array}{lll}71 & 7210 \quad 1870\end{array}$

$70-7210$

$\begin{array}{rr}7060 & 367 \\ 1050 & 860\end{array}$

946

$\begin{array}{rrrr}131 & 5100 & 2,94 & 2 \\ 0 & 50 & 2,74 & 2,7 \\ 375 & 1850 & 2,73 & 2 \\ 480 & 10100 & 2,88 & 2,7\end{array}$

3,02

$\begin{array}{ll}2,77 & 0,27\end{array}$

$2,75 \quad 0,24$

4520

\section{Мигматиты}

1 Вока 315

2 Пыхвн F! 23940

3610

4270

$6200 \quad 5720$

П Пыхви ПII $6 \quad 3749$

4 Мустайыэ 311А 2

5 Нарва H2

6 Ласнамяэ 6010

$\begin{array}{ll}7 & \text { Выхма В } \\ 8 \text { Эллавере }\end{array}$

9 Паламузе Па 2

10 Юминда Ю6

11 Хирвли 8

12 Хаапсалу 3

13 Кохнла 308

14 Tарума 4

15 Ульясте $45 n$

16 Ульясте $47 \mathrm{n}$

17 Ульясте $4^{2}$ п

18 Ульясте 49 n

19 Ухтна у 320

20 Карула 320

21 Печоры 330

$$
\begin{array}{r}
79 \\
37 \\
18 \\
11 \\
2 \\
30 \\
6 \\
695 \\
17 \\
\\
404 \\
2190 \\
9 \\
8 \\
15 \\
55 \\
32
\end{array}
$$

88129100

$\begin{array}{ll}9100 & 49600 \\ 8170 & 33100\end{array}$

1070

384

2980

3100

$\begin{array}{rr}366 & 199000 \\ 765 & 71 \\ 0 & \\ 423 & 5380\end{array}$

$6680 \quad 2,79$

$3820 \quad 147$

261

6120

0
1110

0
275
0

1110

2640

$1790 \quad 1020$

94
405

-

475
6060
1420

1420

1300

457

1280

8970

1 Кейла 117

2 Выхма В

3 Карула 320

4 Юмннда Ю6

Кохила 308

6 Тарума 4

7 Ухтна у320

$\begin{array}{rrr}6 & 105 & 62 \\ 2 & 0 & 0 \\ 10 & 3190 & 153 \\ 2 & 0 & 0 \\ 2 & 36 & 34 \\ 4 & 115 & 51 \\ 6 & 1060 & 421\end{array}$

Ульясте 45 n

Ульясте $46 \mathrm{n}$

3 Ульясте 47 п

Ульясте 48 п $21940-1170$

5 Ульлсте 81

$45600 \quad 22500$

165
0
7760
0
39
147
1770

$\begin{array}{rrrrrrrrrr}22 & 0 & 54 & 2,91 & 2,81 & 2,97 & 0,41 & 3 & 132 & 0 \\ 0 & 0 & 0 & 3,01 & 3,00 & 3,02 & - & - & - & - \\ 632 & 30 & 1280 & 3,00 & 2,73 & 3,07 & 0,40 & 2 & 3980 & 714 \\ 0 & 0 & 0 & 2,86 & 2,86 & 2,87 & - & 2 & 0 & 0 \\ 0 & 0 & 0 & 3,02 & 3,02 & 3,02 & - & - & - & - \\ 49 & 0 & 124 & 3,00 & 2,96 & 3,04 & 0,34 & - & - & - \\ 1920 & 510 & 5530 & 2,94 & 2,91 & 2,98 & 3,62 & - & - & -\end{array}$

\section{Мраморы}

$\begin{array}{rrrrrrrrrr}262 & 0 & 1300 & \overline{1} & \overline{85} & \overline{9} & 1,90 & 9 & 180 & 30 \\ 12400 & 11200 & 13500 & 2,88 & 2,85 & 2.90 & 1,34 & - & - & -\end{array}$

$\begin{array}{lllllllll}2400 & 1980 & 2920 & 2,84 & 2,76 & 2,89 & 4,00 & - & - \\ 1390 & 1240 & 1540 & 2,86 & 2,85 & 2,86 & 2,22 & 1 & 0\end{array}$

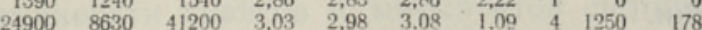

\section{Кварциты}

$\begin{array}{llrrrr}1 & \text { Отепя O2 } & 2 & 33 & 27 & 39 \\ 2 & \text { Ульясте 45п } & 24 & 144 & 40 & 350 \\ 3 & \text { Ульясте 46n } & 20 & 3520 & 50 & 35500 \\ 4 & \text { Ульясте 47n } & 11 & 164 & 0 & 805 \\ 5 & \text { Ульясте 48n } & 28 & 2110 & 0 & 12600 \\ 6 & \text { Ульясте 49n } & 4 & 965 & 850 & 1200 \\ 7 & \text { Ульясте 81 } & 4 & 645 & 195 & 1160 \\ 8 & \text { Ухтна У320 } & 7 & 8150 & 5540 & 12300\end{array}$

$\begin{array}{rr}0 & 0 \\ 593 & 20 \\ 2940 & 31 \\ 4300 & 0 \\ 6340 & 0 \\ 5420 & 990 \\ 13000 & 758 \\ 12200 & 5360\end{array}$

0
2570
20400
23000
39900
10100
29700

$2,64 \quad 2,64$

2,64

- 70

$\begin{array}{llllll}2,69 & 2,62 & 2,80 & 1,67 & - & -\end{array}$

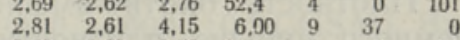

$\begin{array}{lllllll}2,70 & 2,69 & 2,72 & 11,3 & 8 & 0 & 37\end{array}$

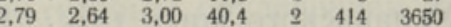

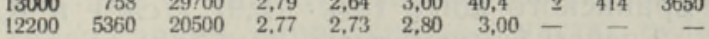


Продом⿻ение табл. $?$

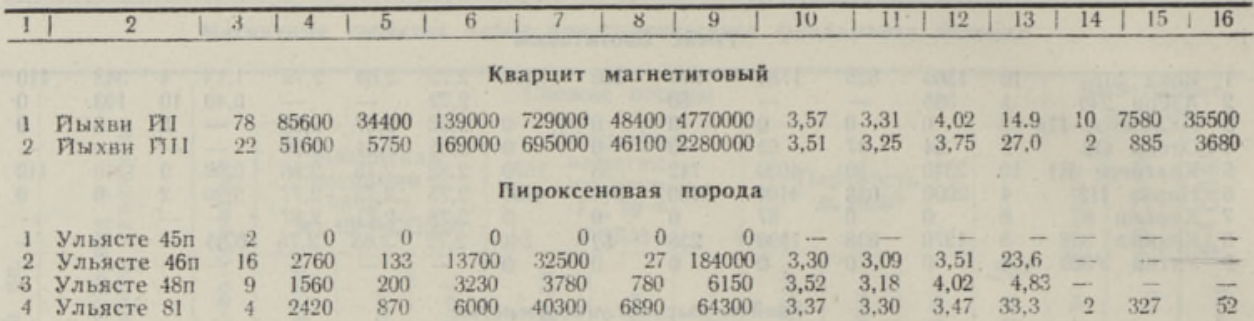

По магнитным свойствам интересны и микроклиновые граниты скважины Иыхви Й. Их можно подразделить на две части: 1) $x^{\prime}$ ср $=187 X$ $\times 10^{-6} \mathrm{CGSM}, I_{n \mathrm{cp}}=50 \cdot 10^{-6} \mathrm{CGSM}, Q=0,40$ (19 образцов) и 2) $x_{\mathrm{cp}}^{\prime}=$ $=2640 \cdot 10^{-6} \mathrm{CGSM}, I_{n \mathrm{cp}}=13800 \cdot 10^{-6} \mathrm{CGSM}, Q=10,45$ (10 образцов). увеличение магнитных свойств последних связано с обогащением пород магнетитом. Причины большой изменчивости $Q$ пока не выяснены.

Распределение магнитных свойств гранитов Эстонии хорошо согласуется со сводными данными Н. В. Дортман и Л. Е. Шолпо по гранитам других районов СССР (рнс. 4).

Породы среднего и основного состава встречаются в Эстонии сравнительно редко. Из них известны лишь кварцевые диориты, габбро-диориты и габбро-нориты.

Плотность кварцевых диоритов скважины Ласнамяэ $60 \sigma_{\mathrm{cp}}=$

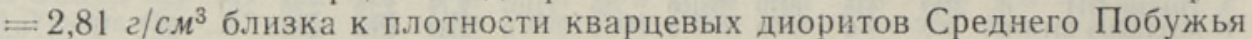

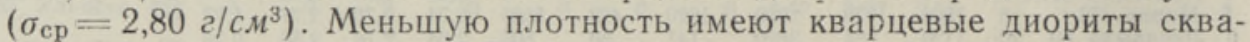

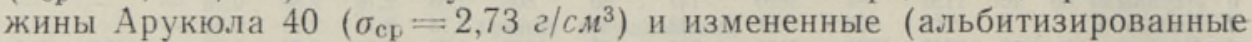
и эпидотизированные) кварцевые диориты скважины Юминда Ю6

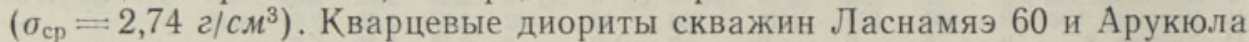
40 имеют близкий состав главных породообразующих минералов и одинаковую структуру. По-видимому, они образуют единый массив. Разница в их средних плотностях объясняется тем, что кварцевые диориты скважины Арукюла 40 несколько более лейкократны.

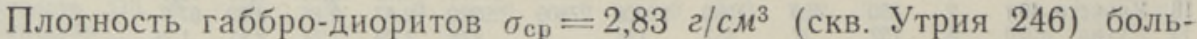

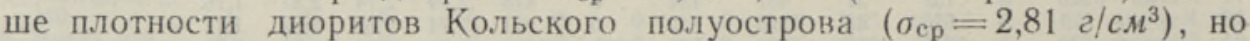
меньше плотности диоритов Украинского щита $\left(\sigma_{\mathrm{cp}}=2,87-2,90 \mathrm{c} / \mathrm{cm}^{3}\right)$.

Габбро-нориты встречены в скважинах Пярну 245 и Выру 66. Плотность их $\left(\sigma_{\mathrm{cp}}=3,03\right.$ г/ $\left.\mathrm{cm}^{3}\right)$ близка к плотности габбро-норитов Карелии $\left(\sigma_{\mathrm{cp}}=3,05 \mathrm{z} / \mathrm{cm}^{3}\right)$. Габбро-нориты Кольского полуострова и центральной части Украинского щита имеют меньшую плотность $\left(\sigma_{\mathrm{cp}}=2,90-\right.$

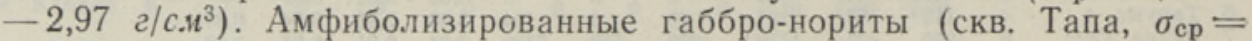
$\left.=2,87 \mathrm{z} / \mathrm{cm}^{3}\right)$ по плотности соответствуют амфиболизированным габброноритам Кольского полуострова $\left(\sigma_{\mathrm{cp}} \equiv 2,87 \mathrm{z} / \mathrm{cm}^{3}\right)$.

Недостаточное количество образцов диоритов и габбро не позволило выявить закономерности распределения их магнитных свойств в Эстонии.

Метаморфические породы представлены слганцами, гнейсами, мигматитами, амфиболитами, мраморами, кварцитами и пироксеновыми породами.

Плотность биотит-амфибол-пироксеновых сланцев $\sigma_{\mathrm{cp}}=2,96 \mathrm{z} / \mathrm{cm}^{3}$ немного меньше плотности амфиболовых сланцев центральной части

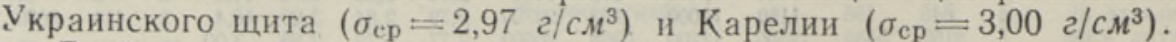

Гнейсы и мигматиты, наиболее распространенные породы в кристал- 
лическом фундаменте Эстонии, характеризуются крайне разнообразным составом и большим колебанием плотности.

Биотитовые гнейсы встречены в 26 скважинах. Плотность их $\left(\sigma_{\mathrm{cp}}=\right.$ $\left.=2,73 \mathrm{2} / \mathrm{cs}^{3}\right)$ соответствует плотности биотит-плагиоклазовых гнейсов

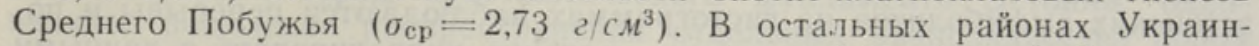
ского щита плотность последних меньше $\left(\sigma_{\mathrm{cp}}=2,63-2,68 \mathrm{z} / \mathrm{cm}^{3}\right)$.

Высокоглиноземистые гнейсы встречены в 17 скважинах. По плотности $\left(\sigma_{c p}:=2,82 \mathrm{z} / \mathrm{cm}^{3}\right)$ они сравнимы с гранат-биотитовыми гнейсами

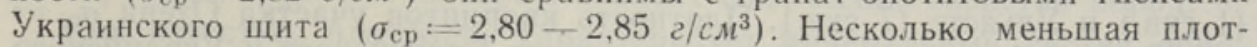
ность кордиерит-силлиманит-гранат-биотитовых гнейсов центральной

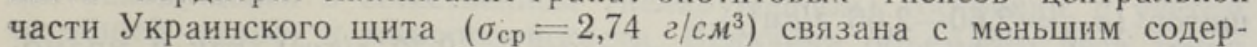
жанием граната в них. В Эстонии им соответствуют высокоглиноземистые гнейсы в скважинах Кабала, Сырумяэ, Тарумаа 4, Мустайыэ $311^{\mathrm{A}}$, Ряэтсма $313^{\mathrm{r}}$ и Хаапсалу 3 с $\sigma_{\mathrm{cp}}: 2,72-2,77 \mathrm{elcm}^{3}$.

«Черные» гнейсы (участок Ульясте, пять скважин, $\sigma_{\mathrm{cp}}=2,81 \mathrm{z} / \mathrm{cm}^{3}$ ) по минералогическому составу являются также высокоглиноземистыми. но отличаются от остальных содержанием графита и сульфидных минералов. Анормальное распределение плотности «черных» гнейсов обусловлено характером изменения в них содержания пирротина.

Биотит-амфиболовые, биотит-пироксеновые и биотит-амфибол-пироксеновые гнейсы объединены в одну группу. Породы этой группы встречены в 11 скважинах. Они характеризуются большой изменчивостью количественных соотношений главных породоюбразующих минералов. Для группы в целом в Эстонии $\sigma_{\text {ср }}=2,87 \mathrm{a} / \mathrm{cm}^{3}$. В отдельных скважинах $\sigma_{\text {ср }}$ биотит-амфиболовых гнейсов изменяется в пределах от 2,73 до $2,872 / \mathrm{cm}^{3}$. Биотит-пироксеновые (скв. Кахала KII) и биотит-амфиболпироксеновые (скв. Вока 315) гнейсы имеют $\sigma_{\mathrm{cp}}$ соответственно 2,88 и 2,90 г/с ${ }^{3}$. В различных районах Балтийского и Украннского шитов плотность этих пород варьируется также в широких пределах:

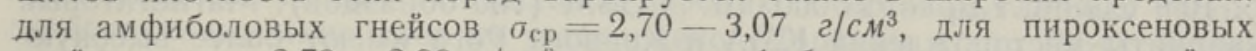

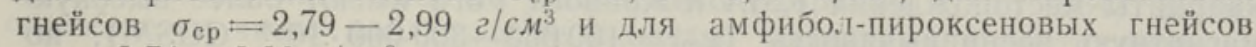
$\sigma_{\mathrm{cp}}=2,74-3,00 \mathrm{z} / \mathrm{Cm}^{3}$.

Мигматиты встречены в 45 скважинах. Их состав тоже очень изменчивый. Значение плотности мигматитов определяется соотношением транитного и гнейсового компонентов и минералогическим составом исходных пород. Мигматиты участка Ульясте $\left(\sigma_{\text {ep }}=2,83\right.$ г/с $\left.{ }^{3}\right)$ характеризуются значительным содержанием пирротина и анормальным распределением плотности, что явилось основанием для выделения их в само-

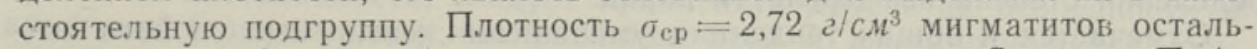
ных районов Эстонии близка к плотности мигматитов Среднего Побужья $\left(\sigma_{c p}=2,70\right.$ г/ $\left.\mathrm{cm}^{3}\right)$. В других районах Украинского щита плотность мигматитов меньше $\left(\sigma_{\text {cp }}=2,60-2,65\right.$ г/c $\left.\mathrm{cm}^{3}\right)$.

Гнейсы и мигматиты имеют довольно близкие магнитные свойства.

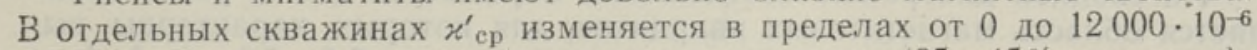
CGSM. Преобладают слабомагнитные породы (35-45\% скважин). Данные о магнитной восприимчивости гнейсов и мигматитов Эстонии хорошо совпадают с данными по другим районам СССР (рис. 4).

Остаточная намагниченность гнейсов и мигматитов Эстонии колеблется в очень широких пределах — от 0 до $40000 \cdot 10^{-6}$ CGSM. По данным Л. Е. Шолпо, в других районах СССР диапазон изменения $I_{n}$ гнейсов и мигматитов гораздо ужже (от 0 до $\left.3000-6000 \cdot 10^{-6} \mathrm{CGSM}\right)$. Высокие значения $I_{n}$ в Эстонии связаны с магнетитовым оруденением на участке Иыхви и с большим содержанием пирротина на участке сульфидного рудопроявления Ульясте. 
Амфиболиты встречены в восьми скважинах. Их плотность $\sigma_{\mathrm{cp}}=$ $=2,96$ г! с $^{3}$ сравнима с плотностью амфиболитов нз всех районов Балтийского и Украинского щитов $\left(\sigma_{\text {cp }}=2,94-3,00\right.$ г/c $\left.{ }^{3}\right)$.

В связи с небольшим количеством определений магнитных свойств эстонских амфиболитов на гистограммах наблюдаются перерывы и поэтому наши данные нельзя вполне уверенно коррелировать с данными Н. В. Дортман и Л. Е. Шолпо.

Кварциты (кроме магнетитовых) встречены на участках Отепя (1 скв.) и Ульясте (7 скв.). Плотность кварцитов участка Отепя $\sigma_{\mathrm{cp}}=$ $=2,62$ г/см ${ }^{3}$ близка к плотности кварцитов Балтийского и Украинского

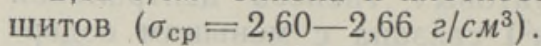

На участке Ульясте как кварциты $\left(\sigma_{\text {ep }}=2,70\right.$ г/см $\left.{ }^{3}\right)$, так и мрамо-

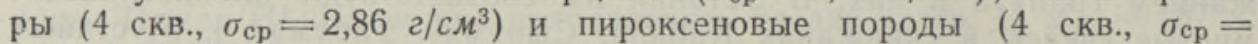
$\left.=3,33 \mathrm{2} / \mathrm{cm}^{3}\right)$ имеют аномально высокое значение плотности, что объясняется большим содержанием в них пирротина и других сульфидных минералов.

Приведенные на рис. 4 гистограммы $\varkappa^{\prime}$ ср и $I_{n \text { ср }}$ практически иллюстрируют лишь изменчнвость магнитных свойств кварцитов участка Ульясте, обусловленную неравномерным распределением в них пирротина. По той же причине магнитные свойства мраморов и пироксеновых пород участка Ульясте изменяются в больших пределах (см. табл. 2).

Магнетитовые кварциты, обнаруженные до сих пор только на участ-

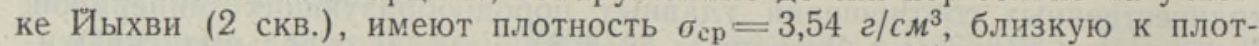
ности магнетитовых кварцитов месторождений КМА и Крнвого Рога $\left(\sigma_{\mathrm{cp}}=3,3-3,7 \quad\right.$ г/C $\left.\boldsymbol{M}^{3}\right)$.

Магнитные свойства магнетитовых кварцитов участка Иыхви очень высокие: $x^{\prime}$ колеблется в пределах от 5800 до $170000 \cdot 10^{-6}$ CGSM, $x^{\prime}{ }_{\mathrm{cp}}=78100 \cdot 10^{-6} \mathrm{CGSM}$ (100 образцов); $I_{n}$ - от 46000 до 4770000 Х $\times 10^{-6} \mathrm{CGSM}, I_{n \mathrm{cp}}=721000 \cdot 10^{-6^{*}} \mathrm{CGSM}$ (100 образцов). Магнетитовые кварциты месторождений КМА и Кривого Рога имеют более высокую магнитную восприимчивость $\left(\varkappa_{\mathrm{cp}}=100000-300000 \cdot 10^{-6}\right.$ CGSM), но остаточная намагниченность их $\left(I_{n \mathrm{cp}}=70000-300000 \cdot 10^{-6}\right.$ CGSM) значительно меньше, чем на участке Йыхви.

При сравнении свежих и выветрелых пород всегда наблюдается уменьшение плотности (табл. 1) в зависимости от степени выветривания, в основном вследствие увеличения пористости пород. Измерения плотности в ходе описания пород могут уменьшить субъективность определения степени выветрелости пород.

Отмечается и общая тенденция уменьшения магнитных свойств породы при выветривании (табл. 2). Әто объясняется частичным перехоцом магнетита в лимонит в результате окисления в зоне выветривания или преобразованием пирротина в пирит.

На сводной диаграмме соотношения параметров $\sigma$ и $I_{z}$ резко выделяется область магнетитовых кварцитов, для которых характерны вы-

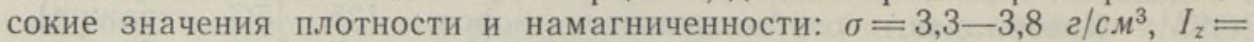
$=40000-3000000 \cdot 10^{-6}$ CGSM.

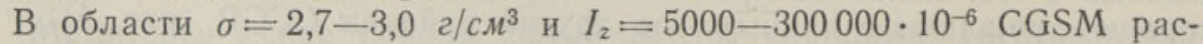
полагаются «черные» и высокоглиноземистые гнейсы, мигматиты и кварциты, связанные с магнетитовым оруденением участка Йыхви или с пирротиновым оруденением участка Ульясте. K этой же области относятся и биотит-амфибол-пироксеновые гнейсы скважины Кахала K II.

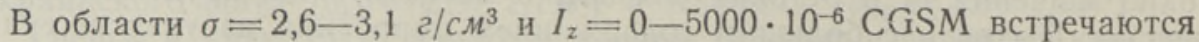
все разновидности пород, кроме магнетитовых кварцитов. По магнит- 
ным свойствам они почти не различаются между собой, а по плотности хорошо выделяются лишь амфиболиты $\left(\sigma=2,9-3,1\right.$ г/с $\left.{ }^{3}\right)$.

Таким образом, как это показывают имеющиеся данные о физических свойствах пород кристаллического фундамента Эстонии, однозначное выделение распространения отдельных разновидностей пород только по интенсивности гравимагнитных полей сопряжено с большими трудностями и возможно лишь в редких случаях. Это объясняется характером факторов, от которых зависят физические свойства пород.

Как известно, плотность характеризует минеральный состав породы, находящейся в естественном (ненарушенном) состоянии, с учетом еe общей макро- и микропористости. Величина объемного веса тонко реагирует и на вторичные изменения минерального состава пород. Она достаточно точно выражает суммарные количественные соотношения породообразующих минералов и является характерной для данной разновидности пород (Ефимов, 1964). Основная трудность заключается в том, что разновидности магматических и метаморфических пород, слагающих самую верхнюю часть кристаллического фундамента, по величине $\sigma$ распространяются в относительно узком интервале значений - от 2,45 до 3,25 г/см ${ }^{3}$ и некоторые разновидности пород могут иметь почти одинаковый состав породообразующих минералов.

Величина $x$ зависит в основном от количества ферромагнитных минералов, входящих в состав горных пород, и, кроме того, от их химического состава и строения кристаллической решетки, а также от размера зерен минералов и характера расположения их в породах. Величина $I_{n}$ зависит от всех тех факторов, которые определяют $\varkappa$. Кроме того $I_{n}$ определяется характером физического процесса, приводящего к ее образованию, и зависит от возраста горных пород.

По Н. В. Дортман, непосредственной зависимости между содержанием ферромагнитных минералов в породах и составом главных породообразующих минералов не установлено (Дортман и др., 1964). Әтим объясняется часто наблюдаемое сходство магнитных свойств различных разновидностей горных пород.

Имеющиеся в нашем распоряжении данные о физических свойствах пород кристаллического фундамента Эстонии недостаточны для выявления статистических закономерностей, позволяющих более уверенно различать отдельные разновидности пород по физическим свойствам. Разумеется, при геологической интерпретации геофизических полей, кроме их интенсивности, следует привлекать другие их особенности и критерии (конфигурация, направление осей и взаимоотношения аномалий и т. д.), позволяющие в некоторых случаях преодолеть отмеченные трудности.

\section{ЛИТЕРАТ У Р А}

Д ортм а н Н. В. и др. 1964. Физические свойства горных пород и полезных ископаемых СССР. «Недра».

Е фи мо в Ф. Н. 1964. Магнитно-фракционно-минералогический анализ горных пород. «Недра».

Методическое руководство по определению физических свойств горных пород и полезных ископаемых. 1962. Госгеолтехиздат.

По бул Э. А., В а хер Р. М. 1964. О физических свойствах пород кристаллического фундамента в районе Ульясте. В сб.: Литология палеозойских отложений Эстонии. 
Руководство по предварительной математической обработке геохимической информации при поисковых работах. 1965. «Недра».

Р у с и н в Б. Ш. 1960. Применение кварцевого магнитометра для измерения магнитных свойств горных пород и руд. Информ, сб. ВСЕГЕИ, № 34.

Институт геологии

Академии наук Эстонской ССР

Управление геологии

Совета Министров Эстонской ССР
Поступила в редакцию 20/III 1968

\section{E. POBUL, R. VAHER, E. ARVISTO}

\section{EESTI KRISTALSE ALUSKORRA KIVIMITE FUUSIKALISED OMADUSED}

Viimase viie aasta jooksul on Eesti NSV-s gravitatsiooniliste ja magnetiliste anomaaliate geoloogilise tōlgendamise kergendamiseks määratud kristalse aluskorra kivimite tihedust (4605 proovi) ja magnetilisi omadusi (1485 proovi).

Uurimistulemused on esitatud kivimitüüpide füüsikaliste parameetrite tabelite (tabelid 1 ja 2), tiheduse jaotumise variatsioonikõverate (joon. 2 ja 3) ja magnetiliste omaduste jaotumise hüstogrammide (joon. 4) kujul.

Selgus, et erinevatele kivimitüüpidele on omane füüsikaliste omaduste suur kattuvus, mistõttu kivimitüüpide eraildamine ainuit gravitatsiooniliste ja magnetiliste anonaaliate intensiivsuse alusel on võimalik vaid üksikjuhtumeil (näit. magnetiliste kvartsiitide esinemise korral).

Olemasolev materjal pole aga veel küllaldane kõigi kivimitüüpide füüsikaliste omaduste jaotumise statistiliste seaduspärasuste iseloomustamiseks.

E. POBUL, R. VAHER, E. ARVISTO

\section{PHYSICAL PROPERTIES OF THE ROCKS OF THE ESTONIAN CRYSTALLINE BASEMENT}

Measurements of the density (of 4605 samples) and magnetic properties (of 1485 samples) of the rock types of the basement in Estonia were carried out during last five years for the :eason that such measurements might aid in the interpretation placed on data obtained by the gravity and magnetic methods of prospecting in this area.

Data on density $\sigma$ are summarized in Table 1. Data on apparent susceptibility *' and remanent magnetization $I_{n}$ are summarized in Table 2. Histograms in Figures 2, 3 and 4 show that there are extensive overlaps among all rock types. Therefore the strength of the gravitational field and the intensity of the magnetic field of a body may give unique clue to its composition only in rare cases (stich as exploration for magnetite quartzites). 